\title{
Kernos
}

Revue internationale et pluridisciplinaire de religion grecque antique

$20 \mid 2007$

Varia

\section{CARASTRO Marcello, La cité des mages. Penser la magie en Grèce ancienne}

Fritz Graf

OpenEdition

Journals

Electronic version

URL: https://journals.openedition.org/kernos/211

DOI: 10.4000/kernos.211

ISSN: 2034-7871

Publisher

Centre international d'étude de la religion grecque antique

Printed version

Date of publication: 1 January 2007

Number of pages: 400-401

ISSN: 0776-3824

Electronic reference

Fritz Graf, "carastro Marcello, La cité des mages. Penser la magie en Grèce ancienne", Kernos [Online], 20 | 2007, Online since 10 February 2011, connection on 08 September 2022. URL: http:// journals.openedition.org/kernos/211 ; DOl: https://doi.org/10.4000/kernos.211

All rights reserved 


\section{Comptes rendus et notices bibliographiques}

Carastro Marcello, La cité des mages. Penser la magie en Grèce ancienne, Grenoble, Jérôme Millon, 2006. 1 vol. $16 \times 24$ cm, 271 p. (coll. Horos). ISBN : 2-84137190-5.

The traditional narrative on the history of magic in Greece understands its rise as the result of Near Eastern influence on Greece; $\mu \dot{\alpha} \gamma \circ \varsigma$, after all, is a Persian word, attested in Greece at the earliest in the late sixth century BCE, and magical rites have close parallels in Mesopotamian texts. Past discussions resulted in two ways of understanding this influence. An older view, palpably committed to an ideologically determined concept of 'pure' Hellenism, had it that magic, its practitioners and its rites introduced themselves into Greece where these rites were previously unknown. A more recent view assumed the presence of such rites and practices already in early Greece, as part and parcel of what the indigenous actors understood as their religious tradition; Near Eastern practices and practitioners, known in Greece through the close contacts with Persia, helped the Greeks to rethink magic and segregate it as a specific field that was negatively viewed. This is the view $\mathrm{C}$ (arastro) subscribes to in the present book, as I would myself.

The book - developed from a PhD thesis at the École des Hautes Études en Sciences Sociales in Paris - presents its argument in three major steps. A first part ("L'avènement des mágol", 17-61) looks at the religious specialists that fifth century Greeks called $\mu$ '́yol, in a Persian term extensively discussed in Herodotus' ethnography, and at the ways Greeks (tragedians, the author of On Sacred Disease, Gorgias) used this ethnographical fact to think about their own religious specialists and their rites, such as diviners or kathartai, but also about the role of language in society. This is convincing and helps to explain why the semantics of $\mu \alpha \dot{\gamma} \sigma \varsigma$ and $\mu \alpha \gamma \varepsilon i \alpha$ in fifth century Greek does not conform to our own semantics, or those of the Imperial epoch. But it is bought with some streamlining of the evidence: the text which some authors, the present writer included, regard as the first attestation of the term in Greece, Heraclitus F 14 DK as cited in Clement of Alexandria, is dismissed as spurious, since its negative connotations fit too well to the Christian condemnation of magic [20f.]; I still would argue that the semantic value of the Heraclitean use is different enough from the later meanings of $\mu \alpha \dot{\alpha} \gamma$ s, both of Clement's time and of the fifth century BCE, that this virtually guarantees the authenticity of the text. This is more than mere quibbling, since it puts the Persian facts that the Greeks perceived, and the way they perceived them, into a sharper focus: Heraclitus, after all, wrote in a world that was under Persian rule.

The second part, "La constellation du thélgein" (65-159) constitutes the core of the book. In a sweeping, but carefully argued and convincing move, C. analyzes the semantic and symbolic nexus of $\theta \varepsilon \dot{e} \lambda \varepsilon \iota \nu$ in early Greece, especially in Homer. From the gods that have the power to 'enchant' humans (C.'s French uses the verb 'méduser' that conveys much better what he is talking about) and thus freeze their own will and self-determination (from Athena and Zeus to Eros who even enchants Zeus [65-99]), C. leads the discussion to other mythical figures that have a similar power - the Sirens and the music associated with them

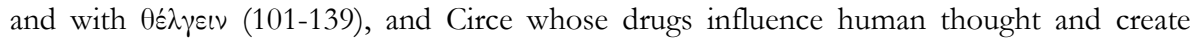
forgetfulness (141-159). C. succeeds to reconstruct a cultural system that reckoned with the power of superhuman beings to suspend human autonomy and self-determination and subject it to another will through the use of words, musical sounds and dangerous 
substances - in short, the cultural nexus in which $\mu \alpha \gamma \varepsilon i \alpha$ would inscribe itself, had the term already existed.

The third part ("Penser la mageía" 163-216) analyzes how $\mu \alpha \gamma \varepsilon i \alpha$ was practiced and thought, once the complex was perceived as a special field of practices. A lengthy chapter treats fifth century binding spells, centered on the very detailed interpretation of two texts, one from Selinus, the other one from Carystus (163-187); this is compelling, although not entirely novel. C. insists on the vital function of writing not just to fix an otherwise fleeting and transient voice but because the very shape of what is written ("la disposition graphique") has ritual power; this might well be, but we would need more proof than just three underlinings in the Selinuntian lead tablet, and the evidence we have about the connection between reciting a binding formula and writing it down does not bear $\mathrm{C}$. out. The final chapter treats Plato - not just the well-known passages where the philosopher condemns magical practices, but the way Socrates, the master of the powerful word, acts as a sorcerer himself: C. succeeds to show that Plato is well inside the Greek symbolic nexus of magical binding and that to describe him as the ancestor of a rationalist rejection of magic projects later values on him. Surprisingly enough, Plato uses the term $\mu \alpha$ dos only once, and not in the passages where he condemns 'magical' practices but in Rep. 9, 572E where the term denotes the sophists: this again shows that to him the ritual practices were part of the religious tradition, not something alien, and the $\mu \dot{\alpha}$ yos was a master of the word.

C. succeeds in his aim to show that what we call magic was an integral part of the symbolic system of the Greek cities from early on, and he can show how the Persian term was used to think about some of its aspects in fifth century Athens; he is somewhat hazy, however, in explaining why there was a need for such a rethinking. And it goes without saying that his methodological stance makes it impossible to prove or disprove Near Eastern imports into this system: whatever wandering practitioners might have brought (and I am still convinced that they brought a considerable amount of private rituals during the Archaic age), was seamlessly integrated. Scholars who are looking for answers on questions of religious import and cross fertilization, then, have to look elsewhere, as do scholars who want to know more on the Persian specialists that lent their name to the magicians, and on magical practices in early Greece. Scholars, on the other hand, who want to know how Greek reflection on the respective phenomena in their own religion started, will have a useful and well-argued study at their disposition.

Fritz Graf

(The Ohio State University, Columbus $\mathrm{OH}$ )

Papalexandrou Nassos, The Visual Poetics of Power. Warriors, Youths, and Tripods in Early Greece, Lanham / Boulder / New York / Toronto / Oxford, Lexington Books, 2005. 1 vol. $15 \times 22$ cm, 293 p. ISBN : 0-7391-0734-8.

Que ce soit du point de vue de l'histoire de l'art et des techniques, des pratiques sociales ou religieuses, les chaudrons à trépied de bronze occupent depuis longtemps une place importante dans l'étude du monde grec. La forte valeur symbolique de l'objet, comme l'A. le rappelle dans son $1^{\text {er }}$ chapitre, a été mise en valeur pour un certain nombre d'usages et de contextes : objet de don dans le monde des héros de l'épopée, offrande de prestige par excellence dans les grands sanctuaires de l'époque géométrique et du haut archaïsme (IX $\mathrm{e}_{\text {- }}$ $\mathrm{VII}^{\mathrm{e}} \mathrm{s}$.), Olympie en tout premier lieu, prix de concours poétiques ou athlétiques, symbole oraculaire, signe de souveraineté... Elle n'a cependant pas été explorée à fond, en particulier pour les époques les plus anciennes, car les études sur les trépieds ont jusqu'ici négligé une des composantes visuelles majeures de ces objets parfois monumentaux : les figurines d'attache en bronze qui, formant paire, ornaient parfois le haut des poignées ou le rebord de la 